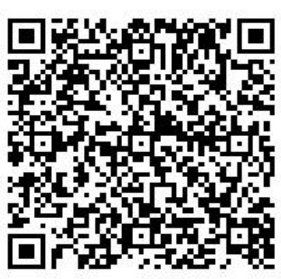

\title{
COVERAGE OF NORTHEAST INDIA IN THE INDIAN MAINSTREAM MEDIA
}

\section{Pooja Basnett*}

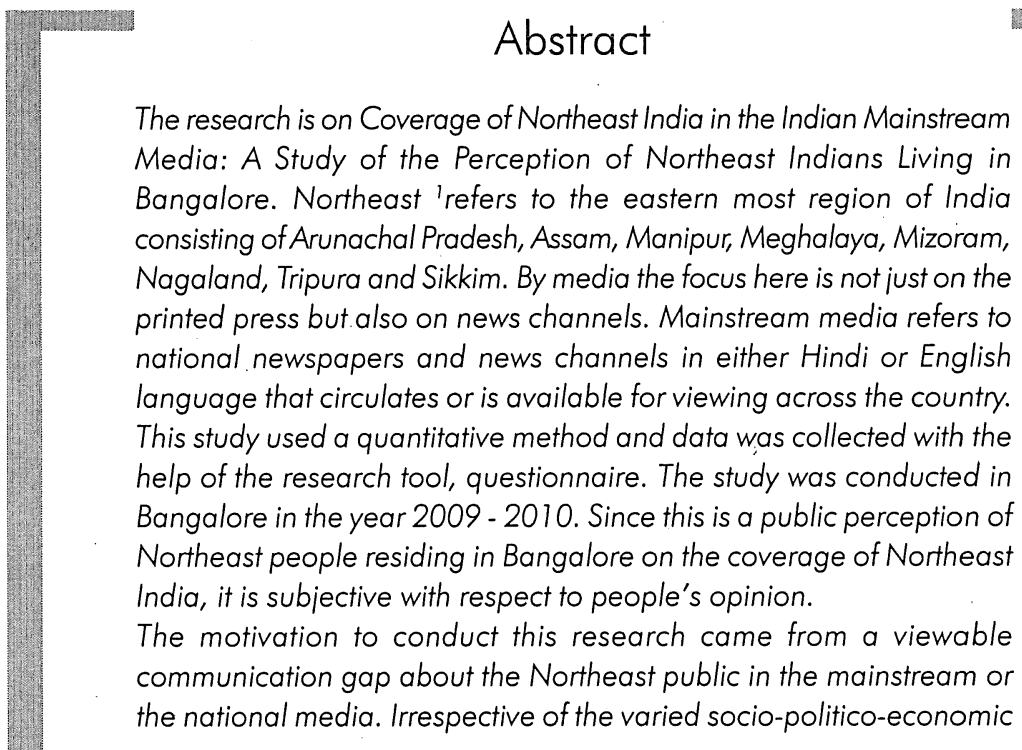

* T John College, Bangalore. 


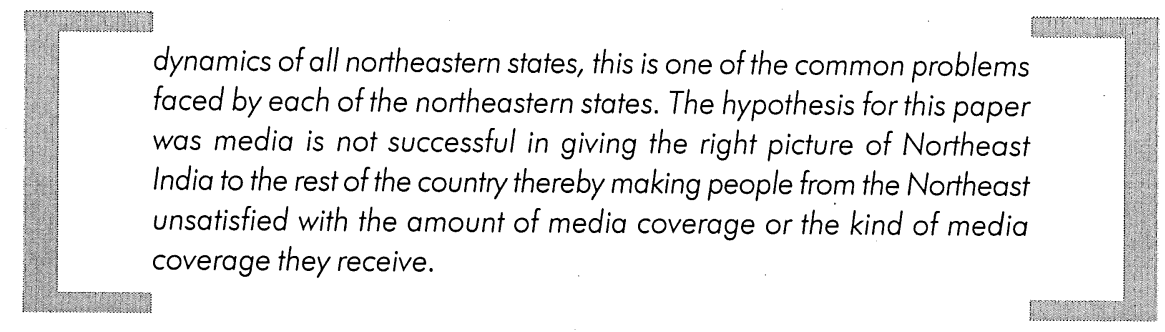

Northeast India is very much a part of India but stands neglected. Day to day events in the Northeast are missed by the media thereby not creating awareness about the region. Media reports on Northeast focus mainly on violence and negative stories which in turn fosters negative image of the region. ${ }^{2}$ The media popularly called as the fourth estate of a democracy has played an important role in informing and creating public opinion in India. However, there seems to be a basic lack of information and news on problems faced and issues concerning the Northeast. Thus the purpose of this research was to find out if this feeling of neglect by media is felt by the people of Northeast. Through this research people from Northeast residing in Bangalore got a chance to express their views on mainstream media coverage of their states. The following sections discuss the findings of this research:

\section{If the people of Northeast are satisfied with the way the media covers their issues?}

The answer to the above question is no. Through this research it has been found out that people from Northeast are not satisfied with the way media covers them. They believe that Northeast is only covered during insurgencies and very less importance is given to cultural, social and developmental category. When compared to even other trouble ridden states or regions the coverage given, ranks miserably lower. Follow-up stories never crop up and positive reporting like the stories on the beauty of Kashmir never arises. However, the reach of media even during insurgencies is very late. The Naga-Manipuri embroil related to the entry of NSCN (IM) Gen Secy Muivah into Manipur resulting in the ongoing blockade of NH-39 lasted for about two months. This economic blockade had a delayed appearance in the mainstream media. Had the media reported on it earlier this blockade would not have lasted two months. The question that arises here is, had this kind of blockade happened in other regions of India would it have lasted for so long and would the media be lethargic to report that too? In fact research shows that such kind of blockades for example the Telangana hunger strike by the TRS party was instantaneously reported by the media and continued to do so till it ended. This level of reporting forced the central government to step in and constitute a committee 
to look into the demands of the activists as well as resolve the matter within a month.

Most national newspapers have local editions but here again the difference is immense. Local news covers just 2-3 pages of the edition. The rest of the edition is from across the country on various topics such as political, cultural or crime. Here again news from Northeast is a rarity.

Consistently greater coverage to other regions is prevalent. In case of the coming state elections in Kerala and West Bengal, coverage on the same has started on a regular basis in the media since January 2011. However, the same was not the case when Sikkim and some other Northeast states went for elections in 2009.

${ }^{3}$ Making news in the Northeast' (2009) by Ammu Joseph in India Together argues that Northeast India is not given space in the media. She asks the logic behind the making of news in the age of $24 \times 7$ media. She states further that only when a major terrorist attack happens in the Northeast region resulting in multiple casualties or a clash between different groups of people on a large scale takes place, only then does the national media puts forth coverage on the incident and the region. A case in point stated by the writer is Manipur which has seen many a new developments and incidents in recent times but has still been unable to garner any space on the national media. Fashion shows, companies announcing their quarterly and annual results, job placements in the IIMs, cricket matches, Bollywood films and film stars romances are regular stories on the national media. In fact these incidents as brought forth by the writer are happening on a regular basis but the media seems to be content in covering the same repeatedly without bringing forth any new angles to a story. Ammu Joseph further argues that Irom Chanu Sharmila also known as the Iron Lady of Manipur is neglected by the media. She questions that while Irom Chanu Sharmila has been continuing her protest in a non-violent manner for close to a decade enjoying local support en masse indicating the nature of the veracity of the political situation; still it does not guarantee her or the struggle itself any coverage. She goes on to clarify that what makes the matter even more appalling is here is a woman who is ready to give her life for the overall betterment of the residents of her home state but still sucha sacrifice goes unnoticed and unreported. Such lack of information further creates unawareness which could lead to various other issues. For example 'You Daft......I'm from Northeast India......not Nepal or China' is a forum in Facebook which has 454 members. It discusses problems faced by the people of Northeast mainly with respect to racism in their own country. These forums are used by people from Northeast to express their views openly.

In reality the trend in media is quite disturbing. While every hunger protest for Telangana gets mass coverage till the matter is resolved, not many know of Irom 
Chanu Shramila or the activists in Sikkim who keep on fighting peacefully for the government to take note of their reservation on the hydel power project at Lepcha reserve of Dzongu. A stark contrast again to that of the Narmada protest and coverage on Medha Patkar.

\section{Where do Northeast people get information about their states from?}

In the absence of interest on part of the mainstream media, people from Northeast India rely on the Internet to share and learn about their states. Online forums, social networking, blogs are the main platforms that are used. Apart from these, talent shows on television like reality shows, cultural programmes, Northeast fests in various cities, Northeast handicraft exhibitions, sports, theatre and art shows are used by the people of Northeast to create awareness about their states.

The most recent trend had been on the reality television in which audience votes to choose the winner. The contestants from Northeast are seen winning many of theses shows due to immense support from their regions. Prashant Tamang and Sorabhee won Indian Idol because of huge support by Northeast people. (Prashant Tamang is not from Northeast but he is from Darjeeling. Darjeeling being very close to Sikkim not just geographically but also socio-culturally and ethnically, many people from Sikkim supported him.). There were poll booths that were put up in Sikkim by the Sikkim Government where the public could walk in at any time and cast their vote for Prashant Tamang free of cost.

\section{Do Northeast people feel alienated?}

Research indicated that people from Northeast do feel alienated from their own country. One online forum that indicates a sign of alienation is a group called ${ }^{4}$ North East India in 'Facebook'. This group has 671 members and is created by Solomon Pudaite, UCCS Grad Student and the officer in charge is Chinpihoi Kipgen who resides in New York. The description of the forum reads "Do your facial features not match the country of origin stated on your passport? Maybe it does, but do you have more of a tolerance for bamboo than the bhangra? rice than chapati? Do people think your filipino, chinese, japanese, korean, south-east asian, mexican but are none of the above? Do you love meat and curry to an unbearable level of hotness? Do a lot of 80 's rock ballads bring back memories of village life? If you answered yes to at least 4 of these questions, well then this group is for you, you north-east Indian. Lets share, discuss and unite. Laugh, learn and love." 
It has been found in this research that people of Northeast are not recognized in their own country. They are mostly confused as being from China, Japan, Thailand, South East Asia, Nepal, Tibet, Bhutan, and Korea. This may be due to the way their facial features are but the irony of this is that even after they mention their states, most Indians are unaware of such states being a part of their country. From Jammu \& Kashmir to Tamil Nadu and from Punjab to West Bengal, these states are easily recognized but that's where the boundary of the nation stops. What lies after West Bengal is a mystery to most.

This shows a total lack of awareness and this is due to less importance given to these states by the government and also the media. Even history and geography school text books feature marginal or negligible content on these states.

Northeast people believe that media is regionally biased in covering issues. Some regions get more coverage than others thereby missing out important news matter. Media's main focus today is on entertainment news. The agenda for media is to sell news, gain readership and TRP's. An article, 5'Fourth Estate on Sale' (2009) in Economic and Political Weekly argues how the Indian media is selling its soul to the market and forfeiting its claim to be an independent estate. If the media becomes a slave to the market, Northeast may never get the needed space in the media.

\section{Conclusion}

This research proves that people from Northeast living in Bangalore are not satisfied with the kind of coverage and the space that is given to Northeast India by the Indian mainstream media. Media coverage if any has been seen to be mostly on Chinese incursions into Indian territory or on attacks by militants. One phenomenon that was observed in the responses given by the respondents was that, the Northeast people wrote 'we' or 'us' when they addressed themselves and they wrote 'them' or 'they' for rest of the people from India. This may also indicate that the Northeast people think of fellow Indians as others and not one among them. This may not only be because of their physical features but also depicts the level of importance they are given in the country. Thus leading to alienation and also raising the potentiality for the birth of identity crises.

Indian media from its very roots has always been actively involved and in instances has been made to involve as a platform for not just providing information to the public but also as a forum for making the voice of the public reach those in power. Be it for the 200 years of colonialism or the long standing aspiration of being a developed country to that of the geographic diversities and distance, media in India has served as a unifying force as well as an equalizer of power. 
Today media is considered to be one of the most powerful weapons that can bring drastic changes in the economy of the country, only if used in a proper way. It is time that media should contribute to the development of Northeast region; educate the common people, widening their thoughts and show that even the Northeastern states are very much a part of India.

\section{Reference}

1. Edited by Madhusree Dutta, Flania Agnes and Neera Adarkar, "The Nation, The State and Indian Identity", Kolkata : Samya Publishers, 1996

2. Edited by Geeti Sen, "Where the Sun Rises When the Shadow Fall", New Delhi : Oxford University Press, 2006

3. Edited by Jayanta Kumar Ray and Rakhee Bhattacharya, "Development Dynamics In Northeast India", New Delhi: Anshah Pub, 2008.

4. Oken Jeet Sandham, "The growing importance of media in north-east India", Kangla Online, 21 Feb 2010 <http://www.kanglaonline.com/index.php?template $\equiv$ kshow\&kid $=31>$

5. Partha Chatteriee, "The Nation and its Fragments", New Delhi: Oxford University Press, 1993

6. Partha Chatterjee, "Wages of Freedom, Fifty Years of the Indian Nation-State", New Delhi: Oxford University Press, 1998.

7. Partha Chatteriee, "OMNIBUS", New Delhi: Oxford University Press, 1999

8. Paul R Brass, "Ethnicity and Nationalism Theory and Comparison", New Delhi : Saga Publications, 1991

9. Prasun Sonwalkar, "Mediating otherness: India's English-language press and the Northeast", Contemporary South Asia, Volume 13, Issue 4, pages 389 - 402, New Delhi : Taylor \& Francis/Routledge Books and Journals, December 2004

10. Rajkumar Sushan Singh, "The Role of media in North-East", .E-Pao, 04th Oct 2007. 10 Feb 2010. <http://www.e-pao.net/epSubPageExtractor.asp? src=features. Focus_On_Media. Role of media in North-East>

11. Ridiff Movies, "North East film makes it to Cannes" 06 May, 2010

$<$ http://movies.rediff.com/report/2010/may/06/first-north-east-film-makes-it-tocannes.htm>

12. SK Aggarwal, "Media Credibility", New Delhi: Mittal Publications, 1989. 


\section{Endnotes}

1 Ministry of Development of North Eastern Region (DONER), "North Eastern States", 02 January 2010.

$<h t t p: / / w w w . m d o n e r . g o v . i n / i n d e x l . a s p ? l i n k i d=81>$

2 Law Resource India, "Media Law", 30 January 2010

$<$ http://indialawyers.wordpress.com/category/media-law/>

3 Ammu Joseph, "Making news in the Northeast", India Together, 22 March 2009. 05 Feb 2010.

4 Facebook, "Northeast India". 05 Feb 2010

$<$ http://www.facebook.com/group.php?gid=2209767722\&v=info>

5 Editorial, "Fourth Estate on Sale", Economic and Political Weekly, December 12 - December 18, 2009. 